\title{
NEW PARASITIC HYMENOPTERA OF THE SUBFAMILY ANTEONINAE FROM THE AMERICAS
}

\author{
By F. A. Fenton
}

Entomologist, United States Bureau of Entomology, Florence, South Carolina

In the following paper are presented descriptions of 23 new species and one new variety of parasitic Hymenoptera of the subfamily Anteoninae. Most of the material studied was from the miscellaneous collection of the U. S. National Museum, and was collected in the New World. Reference to Kieffer's keys is made in many places throughout this paper. The keys referred to are those published in Das Tierreich, family Bethylidae (vol. 41, 1914).

\section{LESTODRYINUS DICHROUS, new species}

Because the parapsidal furrows are greatly reduced, this species traces to Neodryinus in Kieffer's key. It is placed in the genus Lestodryinus because it agrees with all the characters of this genus except the reduced parapsidal furrows.

Female--Length $6 \mathrm{~mm}$. Color testaceous and black as noted below. Head testaceous, broader than long $(13: 7)$; vertex concave, surface with fine longitudinal striations; lateral ocelli located far back on vertex almost to occiput and are approximate, anterior ocellus distant from these, being near frons; head not produced beyond the eyes; occiput truncate; antennae testaceous, third joint unusually long, being more than twice length of scape and second together, and almost three times length of fourth; fifth same length as fourth, thickened distally; sixth to ninth each somewhat shorter than preceding; tenth not quite twice length of ninth. Prothorax testaceous, shining with series of fine transverse striations and a fine thick whitish pubescence; mesoscutum and scutellum black, coarsely rugulose with distinct short white pubescence; postscutellum black with same sculpturing as scutellum, except a smooth area on the disk; legs testaceous, except hind coxae and small areas on middle and hind femora, which are black; chela with median arm extending to second tarsal joint, lamellate at tip and a double row of lamellae extending from here to articular cavity, claw nearly parallel sided and straight except at the tip where it is sharply bent, provided with a single row of toothlike lamellae from near articulation with median arm to subapical tooth; wings with subcostal, median and submedian cells, bifasciate, the larger band extending transversely across the 
wing from the pterostigma. Propodeum black, surface strongly rugose, the raised lines running longitudinally and not being connected with transverse ridges; with same type of pubescence as on thorax. Abdomen smooth, black, with testaceous markings on each side of the segments.

Type locality.-Chapada, South America. Paratype from Santarem, South America.

Described from two specimens collected in April.

Type.-Cat. No. 40182, U.S.N.M. Paratype in writer's collection.

\section{LESTODRYINUS STRIATUS, new species}

Fig. 1

The antennae are missing from this specimen, but otherwise it answers the description of Lestodryinus. The species is nearest Lestodryinus tarraconensis (T. A. Marsh).

Female.-Length $6 \mathrm{~mm}$. Color black, except legs, which are fuscous to testaceous. Head black on vertex, testaceous ventrally, broader than long $(20: 9)$; vertex moderately and broadly concave, surface with more or less irregularly longitudinal striations appearing rugulose; lateral ocelli closer together than to the anterior one; head not produced beyond the eyes; occiput truncate; antennae missing. Entire thorax more or less pubescent; prothorax shining with numerous fine striations, which are more or less transverse on the disk, becoming longitudinal on the sides; lower sides smooth and shining without visible sculpturing; mesoscutum with distinct deeply impressed longitudinal striations, which almost conceal the parapsidal furrows, these are only slightly convergent and extend to margin; scutellum very similar in surface sculpture to mesoscutum except that the striations are more irregular; postscutellum with finely granulated surface partly concealed by white pilosity; legs testaceous to ferruginous, anterior femora, tibiae and tarsi more or less fuscous, middle and hind legs lighter, but with fuscous markings; chela as in Figure 1; wings similar in venation to Lestodryinus dichrous but darker in color, being smoky, with a lighter band extending transversely across the fore wing from the pterostigma. Surface of propodeum with a coarse reticulated sculpturing on the disk and sides, and with a microscopic white pubescence.

Type locality.-Santarem, South America.

Described from one specimen.

Type.-Cat. No. 40183 , U.S.N.M.

\section{PSILODRYINUS GRACILIS, new species}

Fig. 15

Female.-Length $3.7 \mathrm{~mm}$. General color black. Head black, wider than long (10:6); vertex very slightly concave, surface dull 
without definite sculpturing, a cariña extending from median ocellus to bases of antennae; clypeus and mandibles testaceous; antennae long, slightly subclavate, four basal joints, basal part of fifth, and tenth testaceous, rest fuscous, structure as in Figure 15. Prothorax longer than wide $(15: 13)$, with scattered pilosity, divided by an arcuate transverse impression into two lobes, of which the anterior is shorter and wider, the posterior elevated; the entire pronotum is broader anteriorly and narrows posteriorly, so that there is a constriction between it and the mesoscutum, anterior part with many fine striae running outward and downward from the dorsum, posterior portion with indistinct areolation on sides, central elevated part smooth; mesoscutum much wider than prothorax, roughly triangular in outline, covered with scattered fine white hairs, shallowly punctate, without parapsidal furrows; scutellum almost rectangular, shallowly punctate except on its posterior third which is smooth and polished; legs testaceous, posterior unusually long, anterior trochanters and coxae extended; chela well developed; wings brown except unpigmented area extending across the middle from below the pterostigma to the margin of the wing and also apical portion, the pigmented area in this case extending from the radius across the apical cells but not reaching the margin. Propodeum black, in profile the posterior part truncate and with this portion flat, longitudinally striate with smaller cross striations between the longitudinal ones.

Type locality.-Bermuda.

Described from one specimen reared April 7, 1923, from a cocoon on Passiflora leaves from Bermuda. Cocoon intercepted June 29, 1922, by R. G. Cogswell and assigned Federal Horticultural Board, New York No. 1079.

Type.-Cat. No. 40196, U.S.N.M

\section{CYRTOGONATOPUS CLAVICORNIS, new species}

This species traces to Cyrtogonatopus in Kieffer's key because the fourth joint of fore tarsus is less than one-half as long as metatarsus. It differs from Kieffer's brief description of this genus in the following characters: The vertex is not convex, but is practically flat, appearing very slightly indented in front view where the ocelli aro located. The maxillary palpi are apparently six-jointed with four joints visible beyond the geniculation.

Female.-Length $3 \mathrm{~mm}$. General color black with scattered short white pilosity. Head wider than long $(10: 6)$; vertex with dense fine sculpturing appearing areolate under high power; ocelli approximate, equidistant from each other in an equilateral triangle; clypeus fuscous; antennae short, subclavate, scape and second joints fuscous, rest dark brown, almost black, comparative lengths as follows: $4,21 / 2$, $6,3,21 / 2,21 / 2,21 / 2,2 \frac{1}{2}, 2,3$. Pronotum smooth and shining without 
visible sculpturing, posterior half distinctly elevated with a hump in profile and narrower than anterior portion; thoracic constriction about as wide as long, finely rugulose; legs dark reddish brown, anterior coxae and trochanters moderately lengthened, latter with stalk shorter than club; chela with median arm, extending back beyond fourth joint to third, slightly curved and provided with three to four small lamellae, which are replaced by hairs on rest of arm, claw curved, somewhat shorter than median arm. Propodeum anteriorly on dorsum with same type of sculpturing as on head, with distinct transverse carinae, in profile strongly humped, posteriorly sloping gradually to petiole. Abdomen smooth, polished, black.

Type locality.-Brownsville, Tex.

Described from two specimens collected at Brownsville, Tex., May 1, 1904, by H. S. Barber.

Type.-Cat. No. 40199, U.S.N.M. Paratype in writer's collection.

\section{DICONDYLUS LONGICHELATUS, new species}

Figs. 16 and 2

Female.-Length $3.5 \mathrm{~mm}$. General color black, except as noted below. Head almost twice as wide as long (11:6); vertex reddish brown in color, with microscopic areolation, minutely rugulose around ocelli; carina from median ocellus to betweeen bases of antennae; head produced behind the eyes, sides convergent; face, clypeus and mouth parts testaceous, teeth of mandibles dark amber colored; antennae of medium length, fusco-testaceous, the scape, ninth and tenth joints being lighter than the rest (fig. 16). Pronotum ferruginous on sides, in dorsal view black with central ferruginous area, with impressed transverse sulture which divides it into a shorter and wider anterior part and a narrower humped and longer posterior division, with scattered erect hairs, shining, smooth with miscroscopic indistinct punctation; thoracic constriction black, somewhat longer than wide $(7: 5)$, with indistinct longitudinal rugulosity; legs ferruginous, stalk of hind femora of same length as club, anterior metatarsus five times as long as thick, second and third joints of anterior tarsi not much longer than thick, much shorter than metatarsus, fourth anterior tarsal joint same length as latter; chela as in Figure 2. Propodeum black with scattered white erect hairs; anteriorly on dorsum with finely areolate surface sculpture, this becoming less distinct on the raised central portion or disk, posteriorly with fine transverse striations, which extend down the sides. Abdomen polished, brownish black, with scattered white erect hairs.

Type locality.-Bonito Province, Pernambuco, Brazil.

Described from one specimen.

Type-Cat. No. 40184, U.S.N.M. 
PSEUDOGONATOPUS VARIISTRIATUS, new series

Figs. 17 and 4

Female.-Length $3 \mathrm{~mm}$. General color testaceous. Head wider than long $(8: 5)$; vertex moderately concave, shining with a microscopic areolation; antennae testaceous, as long as head, thorax, and thoracic constriction together. (Fig. 17.) Prothorax and thoracic constriction with microscopic aerolation; chela as in Figure 4. Propodeum finely transversely striate anteriorly before spiracles, striations run longitudinally between these, turning and extending down the sides and also some surrounding the spiracles; posterior part of propodeum transversely, arcuately striate, the convex side of the striae posterior. Abdomen smooth, polished.

Type locality.-Rio Piedras, Porto Rico.

Described from one specimen collected January 18, 1913, by T. H. Jones.

Type.-Cat. No. 40198, U.S.N.M.

\section{EUCAMPTONYX SECUNDUS, new species}

Figs. 18 and 3

This species agrees well with Perkin's description of this genus, except that the chelar claw is curved and has a subapical tooth and the vertex is flat.

Female.-Length $5.4 \mathrm{~mm}$. General color ferruginous. Head broader than long $(13: 8)$; vertex flat, surface densely aerolate; ocelli approximate and forming an equilateral triangle, a carina extends from the median ocellus to between bases of antennae, and also one from each lateral ocellus part way to the sides of the vertex; face, clypeus and the four-dentate mandibles testaceous; antennae long and slender, scape, second, seventh to tenth joints testaceous, the rest being fuscous. (Fig. 3.) Pronotum with transverse impression before the middle, sculpture same as that on head becoming more indistinct on the disk of the posterior division; thoracic constriction longer than wide, lighter in color than either prothorax or propodeum, being testaceous, surface densely areolate as head and pronotum; legs unusually long, testaceous to ferruginous with darker fuscous markings on the middle, hind coxae, all femora and tibiae; anterior coxae and trochanters unusually long, stalk of latter at least as long as the swollen tip, metatarsus and fourth tarsal joints longer than the second, third, or fifth, the fourth being longer than the first; the second joint is shorter than the third, being small and transverse; chela as in Figure 18. Propodeum finely transversely striated in front and in back, minutely areolated on the disk, areolations also present between transverse striations, the latter extending down the sides then gradually becoming indistinguishable except posteriorly. Abdomen smooth, polished. 


\section{Type locality.-Western Ohio.}

Described from one specimen collected July 7, 1917, by J. S. Houser in wheat field. One specimen received later, collected by E. D. Ball, Sanford, Fla., on June 2, 1926.

Type-Cat. No. 40203, U.S.N.M.

\section{PACHYGONATOPUS MINIMUS, new species}

This minute species answers to the description of this genus by Perkins, but the maxillary palpi are invisible or broken.

Female.-Length, $2 \mathrm{~mm}$. General color testaceous, abdomen somewhat darker. Head wider than long $(6: 4)$; vertex flat with a slight impression in the middle, surface smooth without visible sculpture; the lateral ocelli closer together than the distance from one of them to the anterior ocellus; head produced behind the eyes, but sides only slightly convergent; antennae short, not extending beyond the prothorax, scape wider than two, three the thinnest and longest joint, but not much difference in thickness of any; apical joints about twice as long as thick, comparative antennal lengths as follows: 7, 4, 7, 5, $5,4,4,4,4,6$. Pronotum smooth, polished, without visible sculpture except on sides where it is minutely areolated; thoracic constriction about same width as length, with a microscopic areolation; legs testaceous, anterior coxae and trochanters not greatly lengthened; median arm of chela extending as far as base of third tarsal joint, lamellate at tip, with a row of small lamellae extending from near here to articular cavity, claw unarmed, curved without subapical tooth. Propodeum with fine microscopic areolation, smooth on the disk. Abdomen testaceous appearing light fuscous in some lights, smooth, polished, with scattered short decumbent pilosity.

Type locality.-Elk Point, South Dakota.

Described from one specimen reared from a jassid by C. N. Ainslie, September 3, 1914.

Type in writer's collection.

\section{PACHYGONATOPUS NEARCTICUS, new species}

Female.-Length $2.4 \mathrm{~mm}$. General color black, except as noted below. Head black, except lower face, clypeus and mandibles, which are testaceous, wider than long $(7: 5)$; vertex flat with a slight impression in the middle, where it is indented in a narrow line extending from the median ocellus to near bases of mandibles, surface polished, indistinctly aerolate; lateral ocelli closer together than to median ocellus; head produced behind the eyes, but sides only slightly convergent; antennae somewhat longer than head and prothorax together, subclavate, fuscous except scape and second joint, which are testaceous; scape thicker than two, which in turn is wider than three, which is the longest joint, four 
thickened distally, five to ten thicker than four, each somewhat broader than the one preceding, apical joints somewhat more than twice as long as wide; comparative antennal lengths as follows: $9,3,10,51 / 2,51 / 2,5,5,5,5,7$. Prothorax minutely areolated, with a distinct transverse impression dividing it into two divisions, of which the posterior is longer and narrower and is strongly elevated or humped; thoracic constriction broad, about as wide as long, with fine areolation, which is more distinct than on pronotum; legs fuscous with lighter testaceous markings; median arm of chela extending as far as third tarsal joint, lamellate at tip, with a row of very small, short, widely spaced lamellae extending along the incrassate part nearly to articular cavity. Propodeum smooth, polished on the disk posteriorly indistinctly areolate. Abdomen smooth, polished.

Type locality.-Sioux City, Iowa.

Described from one specimen reared from a jassid September. 1919, by C. N. Ainslie.

Type in writer's collection.

CHALCOGONATOPUS AREOLATUS, new species

Female.-Length $4.7 \mathrm{~mm}$. General color ferruginous with darker fuscous markings. Head ferruginous with central infuscated area on vertex, wider than long $(13: 8)$; vertex broadly concave, surface minutely and densely areolate; ocelli located near occiput, the lateral ones being somewhat closer together than to median one; mandibles, except amber-colored teeth, scape, second and basal part of third antennal joints testaceous, rest of antennae fuscous, comparative antennal lengths as follows: $5,2,12,9,5,5,5$, $4,4,5$. Prothorax divided by a deep impression into a transverse anterior part and an elevated longer posterior lobe, surface sculpture same as vertex of head; thoracic constriction about as wide as long $(7: 6)$, with same type of surface sculpture as prothorax; legs long, brownish-testaceous, fore trochanters with stalk shorter than club, hind femora and tibiae unusually long; median arm of chela lamellate at tip and with a double row of lamellae extending from near tip almost to articular cavity, these increasing slightly in length and spacing toward the latter; claw slightly curved, without subapical tooth and provided with a row of very small widely spaced teeth. Propodeum surface with same type of sculpture laterally as prothorax but anterior portion and posterior half with transverse striations extending only part way down the sides. Abdomen fuscous to ferruginous.

Paratype similar in structure but different in color, being a clear ferruginous without the darker fuscous markings of the type.

Type locatity.-Falls Church, Va. 
Described from two specimens, type collected July 19, 1923, by R. A. Cushman, and paratype collected July 19, 1906, by D. H. Clemons.

Type--Cat. No. 40189, U.S.N.M. Paratype in writer's collection.

CHALCOGONATOPUS RAPTOR, new species

Figs. 19 and 5

Female.-This is a large, very striking species, being $6 \mathrm{~mm}$. in length. General color black, except legs and abdomen which are ferruginous to fuscous. Head broader than long $(19: 10)$, with short dark scattered pilosity; vertex broadly concave, surface densely areolate; ocelli in equilateral triangle, the lateral ones being situated almost to occiput, carina from median ocellus to between bases of antennae; mandibles except teeth, and clypeus, fuscous; antennae long, fuscous; scape, second, third, and tenth joints lighter in color than rest. (Fig. 19.) Pronotum without transverse impression, appearing rounded in profile, with sparse erect white hairs, densely areolate; thoracic constriction stout, not much longer than wide, gradually widening posteriorly to merge with propodeum, densely areolate, pilose as on pronotum; legs fuscous to testaceous, anterior coxae and trochanters long, latter thickening abruptly proximally so that their basal part or stalk is much shorter than swollen part; chela as in Figure 5. Propodeum indistinguishably merged with thoracic constriction, densely areolate and with same type of pilosity as rest of body. Abdomen fuscous with long distinct, more or less erect sparse pubescence.

Type locality.-Porto Bello, Panama.

Described from one specimen, collected by $\mathrm{A}$. Busck.

Type.-Cat. No. 40190, U.S.N.M.

\section{EPIGONATOPUS TENUIS, new species}

Figs. 21 and 6

Female.-This is a very slender species. Length, $3.3 \mathrm{~mm}$. General color testaceous to fuscous. Head broader than long $(9: 6)$; vertex moderately concave, surface sculpture a feeble microscopic areolation in some parts, mostly smooth and shining; carina extending from median ocellus to between bases of antennae, lateral ocelli nearer together than to median; antennae moderately long, subclavate, scape and second joint testaceous, rest of joints fuscous. (Fig. 21.) Prothorax much narrower than head, with a short, sparse, indistinct pilosity, divided by a deeply impressed arcuate suture into a broader shorter anterior division and a longer narrower elevated posterior part, testaceous but infuscated around pronotal suture, with same surface sculpture as found on vertex of head; thoracic constriction longer than wide, testaceous except infuscated area near union with 
prothorax, with same surface sculpture as noted; chela as in Figure 6. Propodeum fuscous except small area on dorsum near thoracic constriction which is testaceous, with sparse distinct erect hairs, dorsum and sides with distinct fine areolate sculpturing, smooth on disk. Abdomen fuscous, smooth, polished with scattered erect hairs.

Type locality.-Lafayette, Indiana.

Described from one female reared August 21, 1885, from straw. Collected by F. M. Webster and recorded under Bureau of Entomology No. $3413^{06}$.

Type.-Cat. No. 40201, U.S.N.M.

\section{EPIGONATOPUS PLESUIS, new species}

Similar in general appearance, color, and size to Epigonatopus americanus Fenton, but different structurally.

Female.-Length, 2.2-2.6 mm. General color black except as noted below. Head wider than long $(6: 5)$; vertex broadly but slightly concave, shining with faint areolate sculpturing visible only under high power; lateral ocelli farther apart than the distance from one of them to median ocellus; clypeus and mandibles testaceous; antennae testaceous to ferruginous, becoming darker towards tip somewhat longer and more slender than in Epigonatopus americanus, comparative antennal lengths as follows: $6,5,8,6,6,6,5,5,5,7$. Pronotum without any transverse impression, shining with fine, closely spaced, indistinct punctation, smooth on disk and posteriorly; thoracic constriction about as wide as long, with microscopic areolation; anterior coxae, trochanters, stalk of femora, tibiae, and tarsus testaceous; incrassate part of femora fuscous; middle legs testaceous, more or less infuscated, especially coxae and femora; hind coxae black, fading to fuscous at tip, darker than rest of legs, of which the trochanters, stalk of femora, tibiae except tip, and tarsi are testaceous; median arm of chela extending to tip of second tarsal joint, lamellate at tip and with row of lamellae extending from near here almost to articular cavity, claw curved without subapical tooth. Propodeum not strongly humped, minutely granulated on top and sides, with distinct suture between meso and metapleura. Abdomen smooth. polished.

Type locality.-Elk Point, South Dakota.

Described from three speciments reared from jassids August 24, 1914, by C. N. Ainslie.

Type-Cat. No. 40202, U.S.N.M. Paratypes in writer's collection.

\section{AGONATOPUS SUTURALIS, new species}

Fig. 7

Female--Length, $4.2 \mathrm{~mm}$. General color ferruginous, except abdomen which is blackish brown. Head ferruginous, wider than long $(11: 7)$; vertex shallowly concave with surface sculpture a fine microscopic areolation; a carina extends from the median ocellus 
to between the bases of the antennae; first five joints of antennae ferruginous (last five broken off), comparative lengths of antennal joints as follows: $6,4,11,11,8$, third to fifth joints much longer than wide $(11: 1)$, indicating that the antennae are very long and slender. Pronotum divided into a wider, shorter anterior part, and a narrrower elongated elevated posterior division, very similar to Chalcogonatopus, with a fine areolate sculpturing; thoracic constriction much longer than wide $(7: 2)$; with fine areolate surface sculpture; chela as in Figure 7. Propodeum in profile and on sides rounded, so that it is hemispherical in shape, separated laterally by a distinct suture into the meso and metapleura and arising above the thoracic constriction, sparsely pilose and finely areolate on surface. Abdomen minutely areolate, blackish brown.

Type locality.-Tucson, Arizona.

Described from one specimen collected by H. G. Hubbard. Type.-Cat. No. 40200 , U.S.N.M.

\section{DEINODRYINUS VARIABILIS, new species}

Female.-Length, $6.3 \mathrm{~mm}$. General color black except as noted below: Head black except face, clypeus, and mandibles, which are testaceous, teeth of latter dark; vertex rugose with scattered fine white hairs; antennae slender, testaceous except five terminal joints which are fuscous to black, comparative length of joints as follows: $7,5,14,10,7,7,5,5,5,6$. Prothorax slightly wider than long, notched at union with mesoscutum, narrower than latter, surface with dense coarse punctation and with white pilosity, latter being thicker on sides than on dorsum; pronotum black with narrow testaceous band on posterior margin next to mesoscutum; latter smooth, polished, with scattered fine white pubescence, black except ferruginous areas along parapsidal furrows, these deep, somewhat converging, and extending almost the length of the mesoscutum; scutellum black, polished, smooth, posterior margin arcuate; postscutellum black, smooth; legs ferruginous except small infuscated area on hind coxae; chela with median arm long, extending to tip of second tarsal joint, lamellate on tip and with a double row of lamellae extending almost to articular cavity, claw, curved, unarmed, without subapical tooth. Propodeum rugose with fine white hairs. Abdomen smooth, polished, black, appearing dark fuscous in some lights.

The paratypes are similar in size and structure, but coloring is very different and is as follows: General color ferruginous, a larger area on vertex being black and face and antennae testaceous to ferruginous. In one specimen there is a black area on sides of the collar of the pronotum, and the carinae are indistinct, while in the other, three distinct carinae are present extending from the ocelli to the base of the clypeus and also bordering the eyes.

Type locality.-Falls Church, Virginia. 
Described from three specimens, type collected July 27, 1920, by C. T. Greene at Falls Church, Virginia; paratypes July 19, 1923, by R. A. Cushman, at the same locality.

Type-Cat. No. 40191, U.S.N.M. Paratypes in U.S.N.M. and writer's collection.

\section{DEINODRYINUS VARIABILIS CARINATUS, new variety}

Female.-Size smaller than Deinodryinus variabilis, being $5 \mathrm{~mm}$. in length. General color ferruginous. Head black except below ocelli in type and as far as clypeus in the paratype, where the black pigmentation fades into ferruginous; three distinct carinae are present on the face extending from ocelli to the base of the clypeus; the two lateral ones are more distinct, curved inward on the face so that they meet the median; there is also a carina which bounds the inner margin of each eye; the comparative lengths of the antennal joints are somewhat different than variabitis and the punctures on the pronotum are finer. Abdomen fusco-piceous.

Type locality.-Flatbush, New York.

Described from two specimens, type collected at Flatbush, New York, August 2, 1895, by J. L. Zabriskie; paratype collected at Lawrence, Kansas, July 7, 1896, by Hugo Kahl.

Type.-Cat. No. 40192, U.S.N.M. Paratype in writer's collection.

\section{DEINODRYINUS PILOSIFRONS, new species}

Fig. 20

Female.-Similar in size, general coloring, and structure to Deinodryinus variabilis, but with the following differences: Head black except face below bases of antennae, which is testaceous; one carina extends from median ocellus to clypeus; face densely pilose; antennae entirely testaceous, structure as in Figure 20. Thorax testaceous with both small and large punctations irregularly placed; mesoscutum black with shallow punctures regularly placed, parapsidal furrows deep and converging; scutellum and postscutellum black, smooth, and shining; legs testaceous except middle and hind femora and parts of coxae, which are brownish; wings bifasciate, as is characteristic of genus, but bands much lighter in color than in variabilis. Propodeum black, rugose, with scattered white pilosity. Abdomen reddish brown.

Type locality.-Alta Vera, Paz, Guatemala.

Described from one specimen collected by G. P. Goll, April, 1905. Type-Cat. No. 40193, U.S.N.M.

\section{DEINODRYINUS BILOBUS, new species}

Figs. 22 and 8

This species in general answers to the description of Deinodryinus as characterized by Perkins, but the following differences are noted: The head is not greatly produced behind the eyes; the pronotum is 
not elongate, being wider than long (14:8), is transversely impressed at about the middle, and is produced into two distinct lobes back of the impression. These are cariniform and separated from each other at the center. They project upward and forward so that their posterior surface is almost parallel to the mesoscutum. The posterior angles of the pronotum do not quite reach the tegulae and the parapsidal furrows are not distinct, being shallow, convergent, and not reaching to the hind margin of the mesoscutum.

Female.-Length, $7 \mathrm{~mm}$. Prevailing color black except as noted. Head unusually large, black, except clypeus which is ferruginous and mandibles which are testaceous with dark brown teeth, with short white pubescence; vertex rugose with carina extending from median ocellus to bases of antennae and two other carinae extending parallel with the inner margin of the eyes down the face; antennae testaceous except seventh to tenth joints, which are fuscous. (Fig. 22.) Prothorax testaceous, impressed in the middle, posteriorly bilobed as described, pilose, slightly longer than pronotum; mesoscutum black, shining, sparsely pilose and punctate, parapsidal furrows convergent, not deeply impressed and not reaching posterior margin; scutellum black, sparsely punctate and pilose; postscutellum narrow, transverse, black, polished; fore legs testaceous, middle and hind legs much paler testaceous with black markings on coxae and inner face of femora, the black area extending to the outside of the distal third of the posterior femora; middle and hind tibiae and tarsi almost entirely black to brown; the posterior femora testaceous dorsally and on sides of swollen part, black on stalk and ventrally on club; chela as in Figure 8; wings smoky, bifasciate, venation dark brown. Propodeum black, pilose, rugose. Abdomen brownish, with lighter brown markings, smooth, polished.

Type locality.-Santarem, South America.

Described from one specimen.

Type.-Cat. No. 40194, U.S.N.M.

\section{DEINODRYINUS PILOSUS, new species}

Figs. 23 and 9

This specimen is very similar in structure to variabitis but has the following differences:

Female.-Color black except scape of antennae, mandibles, inner side of fore tibiae, fore tarsi including chelae, middle and hind tarsi, which are fuscous to testaceous. The punctation on the pronotum is finer and more even than in variabitis and it is not notched at junction with mesoscutum; chela as in Figure 9 ; dntennae as in Figure 23. The entire body is more or less clothed with short, fine, white hairs.

Type locality.-Chiricahua Mountains, Ariz.

Described from one specimen collected by H. G. Hubbard.

Type-Cat. No. 40195, U.S.N.M. 


\section{CHELOGYNUS PROPODEALIS, new species}

Figs. 25 and 10

Female.-Length, $2.7 \mathrm{~mm}$. General color black except as noteả below. Head wider than long $(8: 5)$; surface of vertex polished with scattered very fine hairs; ocelli in equilateral triangle, lateral ones same distance from occiput as eyes, a distinct carina extends from the median ocellus to between the bases of the antennae; head extended and sides strongly convergent behind the eyes; occiput truncate, mandibles fuscous; antennae testaceous, short, being scarcely longer than head. (Fig. 25.) Pronotum, mesoscutum and scutellum smooth and polished with no visible sculpturing and with fine scattered white hairs; pronotum narrower than mesoscutum and slightly shorter than this $(4: 5)$; mesoscutum without parapsidal furrows; scutellum transverse, much wider than long, rugose along its posterior margin; postscutellum rugose, shorter than scutellum, being almost linear; legs testaceous except posterior femora and tibiae and also middle tibiae, which are brownish, posterior femora darker on the stalk than the club; chela as in Figure 10; wings with two transverse darker bands, the first and larger extending from the pterostigma half way to the tip and almost to opposite margin of wing, the second and smaller extending across the apex of the basal cells, radius angular, proximal part much longer than distal. Propodeum rugose, posteriorly sharply truncate, this part having a large, smooth, median area, bounded by a carina, the enclosed area being in the shape of a five-sided polygon, the sides of which are longer than the divisions at either end. Abdomen fusco-piceous, smooth, polished.

Type locality.-Santarem, South America.

Described from one specimen.

Type.-Cat. No. 40185, U.S.N.M.

CHELOGYNUS MINIMUS, new species

Figs. 24 and 11

Female.-Length, $2.1 \mathrm{~mm}$. General color black, except as noted below. Head wider than long (8:5); surface of vertex dull with short scattered dark hairs; ocelli in an equilateral triangle, lateral ones being about same distance from occiput as eyes, a distinct carina extends from median ocellus to between bases of antennae; head convergent and rounded behind the eyes; occiput truncate, arcuate; mandibles black except teeth, which are brown; antennae fuscous, except sixth to ninth joints, which are testaceous, short but noticeably longer than in propodealis. (Fig. 24.) Pronotum, mesoscutum and scutellum smooth with scattered short dark hairs; pronotum narrower than mesoscutum and shorter than this $(2: 3)$; mesoscutum with parapsidal furrows convergent and extending about half way towards its posterior margin; scutellum transverse, two-thirds length 
of mesoscutum; coxae, trochanters and femora dark brown, tibiae and especially tarsi lighter brown; anterior tarsus with first joint shorter than fourth, second and third subequal much shorter than first; chela as in Figure 11; wings diaphanous, radius angular, proximal part much longer than distal. Propodeum rugose with fine scattered dark pubescence, posteriorly sharply truncate, this part with median area rugose within, the field in the shape of an oblong polygon, the sides of which are much longer than either end, the upper carina of the field arched with arched extensions extending beyond on either side so that posteriorly the propodeum appears to have three fields. Abdomen fusco-piceous.

Type locality.-Barneveld, New York.

Described from one specimen collected June 13 by G. N. Wolcott. Type-Cat. No. 40186, U.S.N.M.

\section{CHELOGYNUS RUGULOSUS, new species}

Figs. 26 and 12

This species traces to Chelogynus canadensis Ashmead in Kieffer's key, but does not agree with the description of this or any other Nearctic species.

Female.-Length, $3 \mathrm{~mm}$. General color black, except as noted. Head reddish brown in color, wider than long (8:5); surface of vertex smooth and shining with a few irregularly placed fine punctures; ocelli in an equilateral triangle, the lateral being somewhat closer to occiput than eyes; head produced and sides convergent behind eyes; face with white hairs, clypeus and mandibles testaceous; scape and second joints of antennae testaceous, rest fuscous. (Fig. 26.) Pronotum longer than wide $(5: 4)$, narrower than mesoscutum, shining with large closely placed punctures anteriorly, so that it appears rugose there, punctations become smaller and more widely spaced posteriorly, with scattered white pubescence; mesoscutum smooth, polished, with distinct parapsidal furrows converging and extending half way towards scutellum; legs testaceous with fuscous shadings on the fore femora and stalk of hind tibiae; chela as in Figure 12 ; wings diaphanous, radius with only a very short distal part appearing almost straight. Propodeum densely rugose, posteriorly truncate with median field bounded by carinae, rugose within, much longer than wide. Abdomen smooth, polished, black.

Type locality.-Saint John, New Brunswick.

Described from one specimen collected July 18 by A. G. Leavitt. Type.-Cat. No. 40187, U.S.N.M.

CHELOGYNUS VIRGINIENSIS, new species

Figs. 27 and 13

F'emale.-Length, $3.6 \mathrm{~mm}$. General color black, except as noted below. Head wider than long $(10: 6)$; vertex black near occiput and 
around ocelli, this merging into brownish red and to testaceous anteriorly, surface roughened, covered with short sparse hairs, these becoming more dense on the face; ocelli in equilateral triangle; head produced and sides convergent behind the eyes; occiput truncate, arcuate; face, clypeus and mandibles except dark amber colored teeth of latter, testaceous, without median carina and densely pilose; antennae testaceous, moderately long. (Fig. 27.) Prothorax wider than long $(6: 3)$, narrower than mesoscutum, coarsely punctate, posterior margin notched at border of mesoscutum, finely pilose on sides; mesoscutum punctate anteriorly, punctures being finer than on pronotum and becoming still smaller and more scattered posteriorly, parapsidal furrows distinct, converging and extending halfway down mesoscutum, scutellum with less distinct punctation than mesoscutum; legs testaceous; chela as in Figure 13; wings diaphanous with venation light, proximal part of radius much longer than distal. propodeum black, pilose, rugose, posteriorly with distinct median field bounded by carinae, carina bordering upper portion of field extended so that upper parts of two lateral fields are visible, posterior face thus appearing to have three fields. Abdomen polished, black; first segment near petiole brownish.

Type locality.-Rosslyn, Va.

Described from one specimen collected July 1, 1913, by R. C. Shannon.

Type.-Cat. No. 40188, U.S.N.M.

\section{PRENANTEON MICROPUNCTATUS, new species}

\section{Figs. 28 and 14}

This specimen traces to the genus Prenanteon in Kieffer's key and agrees well with his description of that genus: Thus, the parapsidal furrows fail to reach the posterior margin of the mesoscutum, extending only halfway to that point; the metatarsus is somewhat longer than the fourth tarsal joint; the median chela arm is provided with lamellae; and the radius is only slightly angled, with the proximal part somewhat shorter than the distal. In the description of the two Nearctic species, this specimen comes closest to Prenanteon bakeri (Kieffer).

Female.-Length, $3.8 \mathrm{~mm}$. General color black, except as noted, body covered with fine microscopic scattered whitish pilosity. Head black, antennae and clypeus testaceous, scape of former lighter; mandibles testaceous, teeth dark amber color; vertex smooth and polished with fine scattered punctation; no median carina present; antennae as in Figure 28. Pronotum not quite as long as mesoscutum, smooth and shining with very fine punctation, which, however, is coarser than on vertex; mesoscutum with parapsidal furrows converging, but extending less than halfway to posterior margin, with 
fine punctation as on vertex; legs testaceous except posterior coxae which are infuscated basally; chela as in Figure 14; wings clear. Propodeum coarsely rugose, in contour gradually rounding off to abdominal petiole, a posterior median area bordered by carinae, but surface dull within this. Abdomen black, smooth, polished.

Type locality.-Nerepis, New Brunswick.

Collected August 22 by A. G. Leavitt.

Type.-Cat. No. 40197, U.S.N.M.

\section{EXPLANATION OF PLATES}

Plate 1

Fig. 1. Chela of Lestodryinus striatus, new species.

2. Chela of Dicondylus longichelatus, new species.

3. Chela of Eucamptonyx secundus, new species.

4. Chela of Pseudogonatopus variistriatus, new species.

5. Chela of Chalcogonatopus raptor, new species.

6. Chela of Epigonatopus tenuis, new species.

7. Chela of Agonatopus suturalis, new species.

8. Chela of Deinodryinus bilobus, new species.

9. Chela of Deinodryinus pilosus, new species.

10. Chela of Chelogynus propodealis, new species.

11. Chela of Chelogynus minimus, new species.

12. Chela of Chelogynus rugulosus, new species.

13. Chela of Chelogynus virginiensis, new species.

14. Chela of Prenanteon micropunctatus, new species.

Plate 2

15. Antenna of Psilodryinus gracilis, new species.

16. Antenna of Dicondylus longichelatus, new species.

17. Antenna of Pseudogonatopus variistriatus, new species.

18. Antenna of Eucamptony $x$ secundus, new species.

19. Antenna of Chalcogonatopus raptor, new species.

20. Antenna of Deinodryinus pilosifrons, new species.

21. Antenna of Epigonatopus tenuis, new species.

22. Antenna of Deinodryinus bilobus, new species.

23. Antenna of Deinodryinus pilosus, new species.

24. Antenna of Chelogynus minimus, new species.

25. Antenna of Chelogynus propodealis, new species.

26. Antenna of Chelogynus rugulosus, new species.

27. Antenna of Chelogynus virginiensis, new species.

28. Antenna of Prenanteon micropunctatus, new species.

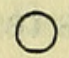




\section{$2 \mathrm{BHL}$ Biodiversity Heritage Library}

1927. "New parasitic Hymenoptera of the subfamily Anteoninae from the Americas." Proceedings of the United States National Museum 72(2704), 1-16.

View This Item Online: https://www.biodiversitylibrary.org/item/100797

Permalink: https://www.biodiversitylibrary.org/partpdf/41024

\section{Holding Institution}

Smithsonian Libraries

\section{Sponsored by}

Biodiversity Heritage Library

\section{Copyright \& Reuse}

Copyright Status: Public domain. The BHL considers that this work is no longer under copyright protection.

This document was created from content at the Biodiversity Heritage Library, the world's largest open access digital library for biodiversity literature and archives. Visit BHL at https://www.biodiversitylibrary.org. 